\title{
Inhibitory Effect of the Punica granatum Fruit Extract on Angiotensin-II Type I Receptor and Thromboxane B2 in Endothelial Cells Induced by Plasma from Preeclamptic Patients
}

\author{
Widya Kusumawati, ${ }^{1,2}$ Kusnarman Keman, ${ }^{3}$ and Setyawati Soeharto ${ }^{4}$ \\ ${ }^{1}$ Dharma Husada Midwifery Academy, Jalan Penanggungan No. 41, Kelurahan Lirboyo, Kecamatan Mojoroto, Kediri, \\ East Java 64117, Indonesia \\ ${ }^{2}$ Midwifery Master Study Programme, Faculty of Medicine, Brawijaya University, Jalan Veteran, Kecamatan Lowokwaru, \\ Malang, East Java 65145, Indonesia \\ ${ }^{3}$ Obstetric and Ginecology Laboratory, Saiful Anwar General Hospital, Faculty of Medicine, Brawijaya University, \\ Jalan Jaksa Agung Suprapto No. 2, Malang, East Java 65122, Indonesia \\ ${ }^{4}$ Pharmacology Laboratory, Faculty of Medicine, Brawijaya University, Jalan Veteran, Kecamatan Lowokwaru, \\ Malang, East Java 65145, Indonesia
}

Correspondence should be addressed to Widya Kusumawati; widya.koesoemawati@gmail.com

Received 5 September 2015; Revised 16 November 2015; Accepted 20 December 2015

Academic Editor: Gerardo E. Guillén Nieto

Copyright (C) 2016 Widya Kusumawati et al. This is an open access article distributed under the Creative Commons Attribution License, which permits unrestricted use, distribution, and reproduction in any medium, provided the original work is properly cited.

\begin{abstract}
This study aims to evaluate whether the Punica granatum fruit extract modulates the Angiotensin-II Type I receptor (AT1-R) and thromboxane B2 level in endothelial cells induced by plasma from preeclamptic patients. Endothelial cells were obtained from human umbilical vascular endothelial cells. At confluence, endothelial cells were divided into five groups, which included endothelial cells exposed to $2 \%$ plasma from normal pregnancy (NP), endothelial cells exposed to $2 \%$ plasma from preeclamptic patients (PP), and endothelial cells exposed to PP in the presence of ethanolic extract of Punica granatum (PP $+\mathrm{PG})$ at the following three doses: 14; 28; and 56 ppm. The expression of AT1-R was observed by immunohistochemistry technique, and thromboxane B2 level was done by immunoassay technique. Plasma from PP significantly increased AT1-R expression and thromboxane B2 levels compared to cells treated by normal pregnancy plasma. The increasing of AT1-R expression significantly $(P<0.05)$ attenuated by high dose treatments of Punica granatum extract. Moreover, the increasing of thromboxane B2 levels significantly $(P<0.05)$ attenuated by lowest dose treatments of Punica granatum extract. We further concluded that Punica granatum fruit protects and inhibits the sensitivity of endothelial cells to plasma from preeclamptic patients due to inhibition of AT1-R expression (56 ppm) and reduced thromboxane B2 levels (14 ppm).
\end{abstract}

\section{Introduction}

Preeclampsia is a pregnancy-associated disorder characterized by collective symptoms such as increasing blood pressure and proteinuria. This complex syndrome leads to maternal and fetal morbidity and mortality. The pathophysiological mechanism of this syndrome remains unclear. Predisposing demographic, genetic, and environmental risk factors was involved in the defect of the placenta. Defective placentation and improper trophoblast invasion of the myometrium cause reduction in uteroplacental perfusion pressure which stimulates the release of complex circulating bioactive factors [1-5].

The dysfunction of the vascular system found in preeclampsia is associated with the production of vasoactive factors by endothelial cells. One pathway which is involved in this dysfunction is the renin angiotensin aldosterone system. A low sensitivity to the vasoconstrictor angiotensin-II (AngII) is found in normal pregnancy, but this sensitivity increases in preeclampsia case prior to the clinical onset of disease [69]. Ang-II exerts its effects via two receptors and its binding to the Ang-II Type I receptor (AT1-R) induces contraction [7]. 
Preeclampsia is also associated with disproportional of serum factors, including thromboxane and prostacyclin with undefined mechanism of this release. The thromboxane levels are found to significantly increase only in severe preeclampsia. The ratio of thromboxane greatly increases in severe cases $[10,11]$. Besides, the serum was obtained from preeclampsia which also contains cytotoxic factors that can damage endothelial cells. So this pathomechanism must diminish or be inhibited by drug or other pharmacological agents. Punica granatum is an Indonesian ancient fruit, the main compounds of which are polyphenols and carbohydrates [12] that may act as an alternative herbs therapy in preeclampsia treatment [13-16]. As far as we know, there was no previous study which evaluated the effect of Punica granatum on AT1-R and thromboxane B2 level of endothelial induced by preeclamptic plasma, so this pathomechanism must diminish or be inhibited by drug or other pharmacological agents. Therefore, this study is aimed at investigating whether Punica granatum fruit extracts modulate the AT1-R and thromboxane B2 level in endothelial cells challenged by plasma from preeclamptic patients.

\section{Material and Methods}

2.1. Endothelial Cells Isolation and Culture. The endothelial cells were collected from the human umbilical vein. This umbilical vein was obtained from pregnant mother with the following characteristics: a healthy and at term (38 weeks of gestation) pregnancy, hemoglobin level $\geq 10 \mathrm{~g} / \mathrm{dL}$, having performed a section cesarean delivery. Immediately postpartum, $10 \mathrm{~cm}$ of the umbilical cord was inserted in buffer $(100 \mathrm{~mL}$ Hank's Balance Salt Solution (HBSS), gentamycin (GENTA, MERCK, Germany), sodium hydrogen bicarbonate, $4 \mathrm{~mL}$ red phenol, 2 mL HEPES solution, and deionized water) and kept cold in the transportation process to target laboratory. In order to get the best result, the isolation was performed under 12 hours after umbilical cord collection [17].

When the umbilical cord was in clean condition, a cannula was inserted $( \pm 1.5 \mathrm{~cm})$ at one edge of the vein and secured tightly using suture. After that, the veins were gently washed with PBS and then closed off tightly at the distal edge to the cannula. After washing, the collagenase (SIGMA, type HA, C-6885) $(5 \mathrm{mg} / 10 \mathrm{~mL} ; 10 \mathrm{~mL})$ was injected into the vein by $10 \mathrm{~mL}$ syringe then incubated at $37^{\circ} \mathrm{C}$ for 8 minutes. The cell pellet was suspended in $4 \mathrm{~mL} 199$ culture medium (SIGMA, M-5017, USA) which was supplemented with a cocktail (gentamycin, bicarbonate phenol red, $20 \%$ fetal bovine serum (GIBCO), and $20 \mathrm{~mL}$ new born calf serum (SIGMA, N-4637, USA). This cell suspension was cultivated into wells that had been coated with gelatin (SIGMA, G1393). Cells were allowed to achieve the confluency at $37^{\circ} \mathrm{C}$ and $5 \%$ $\mathrm{CO}_{2}$.

2.2. Isolation of Plasma Preeclamptic Patients. For blood collection, normal pregnancy and preeclamptic patients all gave informed consent. Written informed consent should be completed by Ethics Committee of Health Research, Medical Faculty, Brawijaya University, Malang, East Java, Indonesia.
The clinical signs of preeclamptic patients were systolic blood pressure $(\geq 160 \mathrm{mmHg})$ and diastolic blood pressure $(\geq 110 \mathrm{mmHg}$ ) in two measurements (4-6 hours between measurements) and proteinuria $(\geq 2+)$ on dipstick. Plasma was isolated from $2 \mathrm{~mL}$ of whole blood in citrate anticoagulant. The blood was centrifuged at $1000 \mathrm{~g}$, for 10 minutes at $-40^{\circ} \mathrm{C}$. Plasma was used in cell culture experiments as detailed in the following sections [17].

2.3. Cell Treatment. Once confluent, cells treatments were divided into 5 replicated experiments including endothelial cells exposed to $2 \%$ plasma from normal pregnancy (NP); cells treated with $2 \%$ plasma preeclamptic patients (PP); PP + the ethanolic extract from Punica granatum (PG) fruit at several doses, including 14 ppm; 28 ppm; and 56 ppm.

2.4. Punica granatum Extraction. Punica granatum, in dry condition was obtained from Bandungan village, Semarang, Central Java, Indonesia. The extraction was initiated by grinding the meat of the Punica granatum fruit using 400 mesh grinder. Subsequently, maceration was performed on 100 gram of powder (70\% ethanol (1:3 ratio) for $2 \times$ 24 hours). After that, polyphenolic extract was separated from the Punica granatum sedimentation. This polyphenolic extract was dried by vacuum oven for 8-9 hours at $45-50^{\circ} \mathrm{C}$. This procedure yields 25 grams of Punica granatum extract.

2.5. Analysis of AT1-R Expression. AT1-R expression of endothelial cells was measured by immunohistochemistry technique. The details of the methods were explained formerly [18]. We used Rabbit Anti-Angiotensin-II Type 1 Receptor Polyclonal Antibody (Bioss Antibodies, Catalog bs0630R, Woburn, Massachusetts, USA).

2.6. Analysis of Thromboxane B2 Levels. The levels of thromboxane B2 were determined using ELISA technique (R\&D system; catalog KGE011, Minneapolis, MN, USA). The procedure was performed according to the instructions from the manufacturer.

2.7. Statistical Analysis. Data are presented as mean \pm standard deviation and differences between groups were analyzed using one-way analysis of variance using SPSS 17.0 statistical package software. The post hoc test was used to examine significant differences among treatments $(P<0.05$ was considered statistically significant).

\section{Results}

Table 1 and Figures 1 and 2 present the AT1-R expression in the endothelial cells from each group. The AT1-R expression is significantly higher in the PP group compared to the NP group $(P<0.05)$. The highest dose of the Punica granatum fruit extract significantly prevented $\mathrm{PP}$-induced increase in AT1-R expression $(P<0.05)$ reaching a similar level with the NP group $(P>0.05)$.

Table 2 and Figure 3 present the thromboxane B2 level in the medium of endothelial cells from each experimental 
TABLE 1: Level of Angiotensin-II Type I receptor in endothelial cells induced by plasma preeclamptic patients.

\begin{tabular}{|c|c|c|c|c|c|}
\hline \multirow{2}{*}{ Expression } & \multirow{2}{*}{ NP } & \multirow{2}{*}{ PP } & \multicolumn{3}{|c|}{$\mathrm{PP}+$ Punica granatum } \\
\hline & & & $14 \mathrm{ppm}$ & $28 \mathrm{ppm}$ & $56 \mathrm{ppm}$ \\
\hline AT1-R (\% cells) & $6.72 \pm 2.91$ & $42.19 \pm 15.63^{\mathrm{a}}$ & $39.78 \pm 5.67^{\mathrm{a}}$ & $25.33 \pm 7.57^{\mathrm{ab}}$ & $11.25 \pm 3.31^{\mathrm{bc}}$ \\
\hline
\end{tabular}

Note: values are presented as mean $\pm \mathrm{SD} ;{ }^{\mathrm{a}} P<0.05$ in comparison with NP group; ${ }^{\mathrm{b}} P<0.05$ in comparison with $\mathrm{PP}$ group; ${ }^{\mathrm{c}} P<0.05$ in comparison with first dose (14 ppm) Punica granatum group; NP: plasma from normal pregnancy; PP: plasma from preeclamptic patients; ppm: part per million.

TABLE 2: Thromboxane B2 level in endothelial cells induced by plasma preeclamptic patients.

\begin{tabular}{|c|c|c|c|c|c|}
\hline \multirow{2}{*}{ Level } & \multirow{2}{*}{ NP } & \multirow{2}{*}{$\mathrm{PP}$} & \multicolumn{3}{|c|}{$\mathrm{PP}+$ Punica granatum } \\
\hline & & & $14 \mathrm{ppm}$ & $28 \mathrm{ppm}$ & $56 \mathrm{ppm}$ \\
\hline $\mathrm{TXB}_{2}(\mathrm{pg} / \mathrm{mL})$ & $0.00096 \pm 0.0002$ & $0.00110 \pm 0.0001^{\mathrm{a}}$ & $0.00072 \pm 0.0002^{\mathrm{b}}$ & $0.00065 \pm 0.0002^{\mathrm{ab}}$ & $0.00065 \pm 0.0001^{\mathrm{ab}}$ \\
\hline
\end{tabular}

Note: values are presented as mean $\pm \mathrm{SD} ; \mathrm{TXB}_{2}$ : thromboxane $\mathrm{B} 2 ;{ }^{\mathrm{a}} \mathrm{P}<0.05$ in comparison with $\mathrm{NP}$ group; ${ }^{\mathrm{b}} \mathrm{P}<0.05$ in comparison with $\mathrm{PP}$ group; ppm: part per million; pg/mL: picogram/milliliter.

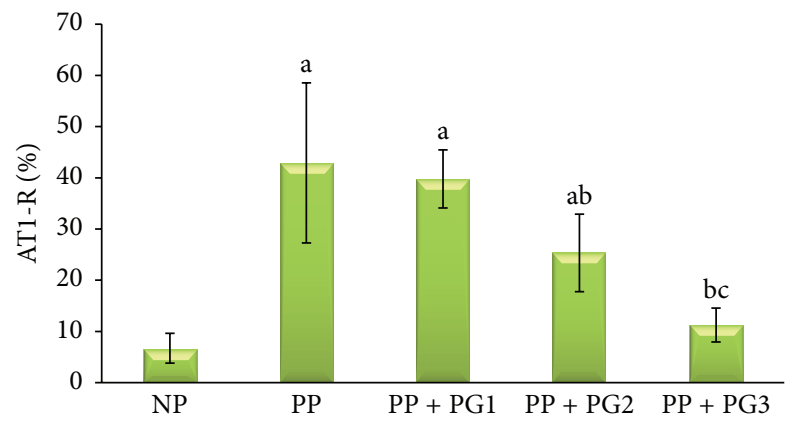

Figure 1: The endothelial expression of Angiotensin-II Type I receptor was measured by immunohistochemistry technique. The data represents 5 replicated experiments (mean value $\pm \mathrm{SD}$ ), ${ }^{\mathrm{a}} \mathrm{P}<$ 0.05 in comparison with endothelial cells exposed to $2 \%$ plasma from normal pregnancy (NP) group; ${ }^{\mathrm{b}} \mathrm{P}<0.05$ in comparison with endothelial cells exposed to $2 \%$ plasma from preeclamptic patients (PP) group; ${ }^{\mathrm{C}} P<0.05$ in comparison with first dose (14 ppm) Punica granatum group.

group. The thromboxane B2 levels were significantly greater in the PP group compared to the NP group $(P<0.05)$. Out of $14 \mathrm{ppm}, 28 \mathrm{ppm}$, and $56 \mathrm{ppm}$ of extract, only lowest dose of the Punica granatum fruit extract significantly prevented PP-induced increase in thromboxane B2 levels $(P<0.05)$ reaching a similar level with the NP group $(P>0.05)$.

\section{Discussion}

Women with preeclampsia, on the other hand, did not show this resistance to angiotensin-II, which can already be observed as early as week 10 of gestation and thus well before the onset of clinically apparent symptoms. This increased sensitivity was still present 8 months after pregnancy [19]. There are several explanations for this increase in sensitivity. First, the adipose tissue of patients with preeclampsia displays elevated AT1-R. Increased AT1-R expression may also be present in other tissues [20]. In this study, this is the first report which found that the AT1-R expression was significantly higher in the PP group compared to the NP group $(P<0.05)$. This study showed that endothelial cell modulates the AT1-R expression coming from exposure to preeclamptic plasma. The highest dose of the Punica granatum fruit extracts significantly prevented PP-induced increase in AT1-R expression $(P<0.05)$ reaching a similar level with control $(\mathrm{NP})$ group $(P>0.05)$. Our finding indicated that the Punica granatum fruit extract inhibits the signal for the AT1-R expression of endothelial cells.

In this study, the thromboxane B2 level is significantly greater in the PP group compared to the NP group $(P<0.05)$. This finding indicates that plasma from preeclamptic patient contains bioactive factor for activating the cyclooxygenase enzyme. The phospholipase A2 activity acts to catalyze the hydrolysis of membrane phospholipids sn-2 ester bond to produce an arachidonic acid, which is the substrate of cyclooxygenase. This enzyme will convert the arachidonic acid into thromboxane. In fact, elevated maternal levels of soluble phospholipase A2 and arachidonic acid have been reported in women with preeclampsia [21, 22]. Besides, the trophoblast cells from preeclamptic placentas secreted higher level of phospholipase A2 compared with the normal placentas. This increase of phospholipase A2 activity is positively correlated to the greater levels of thromboxane $[22,23]$. Out of $14 \mathrm{ppm}, 28 \mathrm{ppm}$, and $56 \mathrm{ppm}$ of extract, only lowest dose of the Punica granatum fruit extract significantly prevented PP-induced increase in thromboxane B2 level $(P<$ $0.05)$ reaching a similar level with NP group $(P>0.05)$. We hypothesized that Punica granatum fruit extract inhibits the cyclooxygenase enzyme for thromboxane production. Several reports showed that Punica granatum fruit extract acts as cyclooxygenase inhibitors $[24,25]$.

In conclusion, Punica granatum fruit extract protects and inhibits the sensitivity of endothelial cells to plasma from preeclamptic patients due to inhibition of AT1-R expression (56 ppm) and reduced thromboxane B2 levels (14 ppm).

\section{Ethics}

This study was approved by the Ethics Committee of Health Research, Medical Faculty, Brawijaya University, Malang, East Java, Indonesia.

\section{Conflict of Interests}

The authors declare that there is no conflict of interests regarding the publication of this paper. 


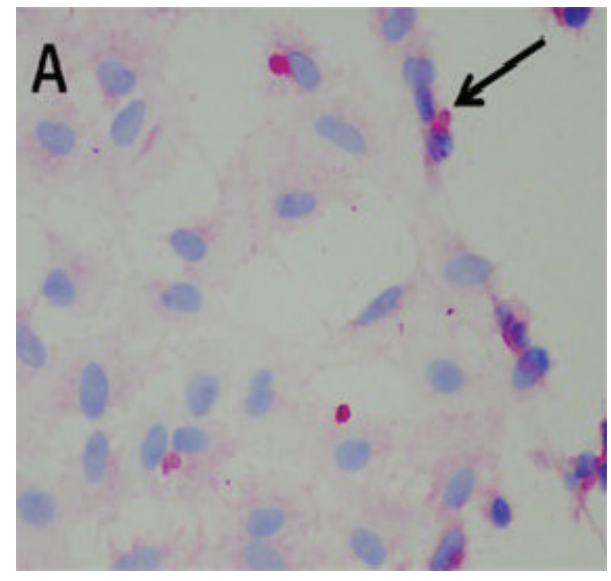

(a)

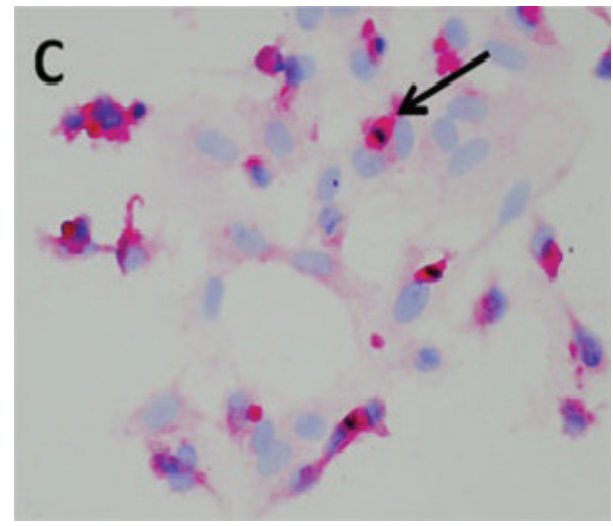

(c)

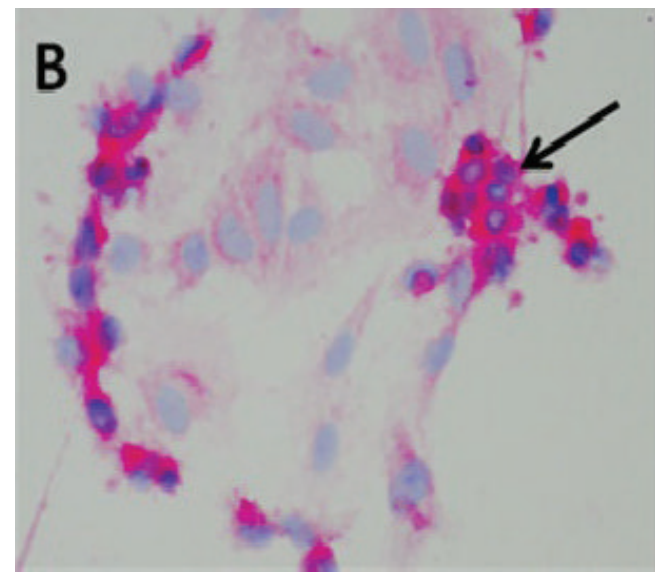

(b)

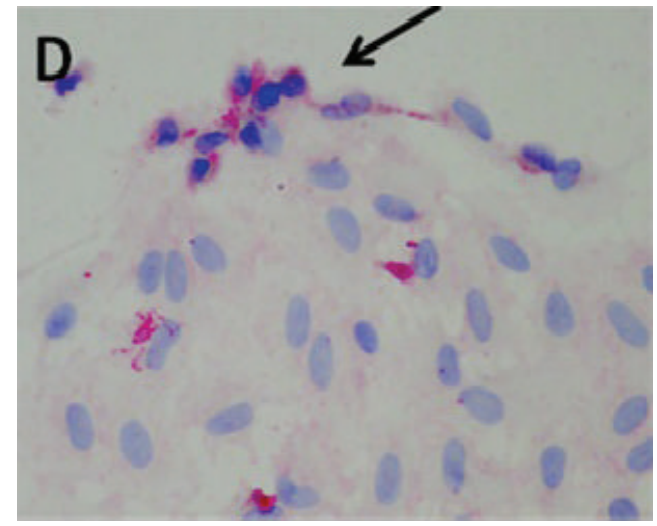

(d)

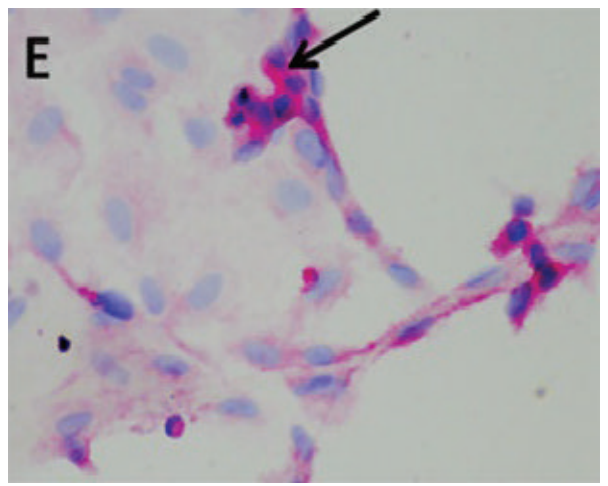

(e)

FiguRE 2: Representative micrograph of Angiotensin-II Type I receptor (black arrow) in endothelial cells induced by plasma preeclamptic patients. Endothelial cells exposed to $2 \%$ plasma from normal pregnancy (a), endothelial cells exposed to $2 \%$ plasma from preeclamptic patients (b), and endothelial cells exposed to PP in the presence of ethanolic extract of Punica granatum (PP + PG) at the following three doses: 14 (c); 28 (d); and 56 ppm (e). 


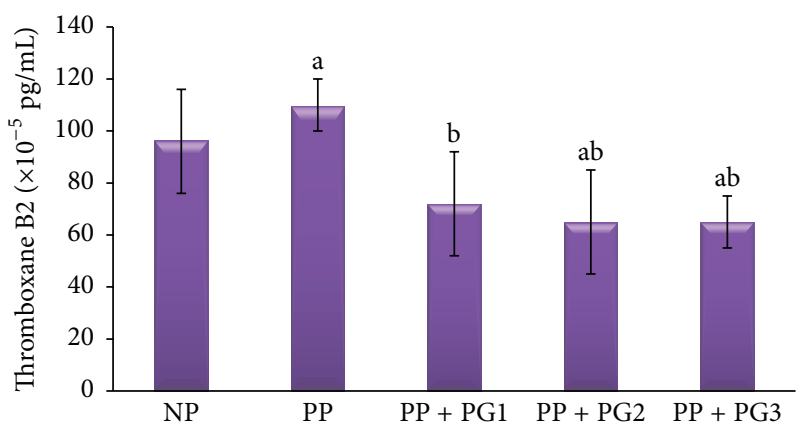

Figure 3: The level of thromboxane B2 in endothelial cells of each experimental group. Values are presented as mean $\pm \mathrm{SD} ;{ }^{\mathrm{a}} \mathrm{P}<0.05$ in comparison with endothelial cells exposed to $2 \%$ plasma from normal pregnancy (NP) group; ${ }^{b} P<0.05$ in comparison with endothelial cells exposed to $2 \%$ plasma from preeclamptic patients (PP) group; PP + G1: first-dose Punica granatum administered group; PP + G2: second-dose Punica granatum administered group; $\mathrm{PP}+\mathrm{G} 3$ : third-dose Punica granatum administered group; $\mathrm{pg} / \mathrm{mL}$ : picogram/milliliter.

\section{Acknowledgment}

The authors acknowledged all technicians from the Laboratory of Biomedical Science and Physiology Molecular for helping this experiment.

\section{References}

[1] A. Molvarec, Á. Jermendy, B. Nagy et al., "Association between tumor necrosis factor (TNF)- $\alpha$ G-308A gene polymorphism and preeclampsia complicated by severe fetal growth restriction," Clinica Chimica Acta, vol. 392, no. 1-2, pp. 52-57, 2008.

[2] B. M. Sibai, "Intergenerational factors. A missing link for preeclampsia, fetal growth restriction, and cardiovascular disease?" Hypertension, vol. 51, no. 4, pp. 993-994, 2008.

[3] P. Merviel, L. Carbillon, J.-C. Challier, M. Rabreau, M. Beaufils, and S. Uzan, "Pathophysiology of preeclampsia: links with implantation disorders," European Journal of Obstetrics Gynecology and Reproductive Biology, vol. 115, no. 2, pp. 134-147, 2004.

[4] E. Padmini, U. Venkatraman, and L. Srinivasan, "Mechanism of JNK signal regulation by placental HSP70 and HSP90 in endothelial cell during preeclampsia," Toxicology Mechanisms and Methods, vol. 22, no. 5, pp. 367-374, 2012.

[5] N. Benjamin, J. Rymer, S. D. Todd, M. Thom, and J. M. Ritter, "Sensitivity to angiotensin II of forearm resistance vessels in pregnancy," British Journal of Clinical Pharmacology, vol. 32, no. 4, pp. 523-525, 1991.

[6] R. A. Irani and Y. Xia, "The functional role of the reninangiotensin system in pregnancy and preeclampsia," Placenta, vol. 29, no. 9, pp. 763-771, 2008.

[7] N. F. Gant, G. L. Daley, S. Chand, P. J. Whalley, and P. C. MacDonald, "A study of angiotensin II pressor response throughout primigravid pregnancy," Journal of Clinical Investigation, vol. 52, no. 11, pp. 2682-2689, 1973.

[8] M. A. Brown, J. Wang, and J. A. Whitworth, "The reninangiotensin-aldosterone system in pre-eclampsia," Clinical and Experimental Hypertension, vol. 19, no. 5-6, pp. 713-726, 1997.

[9] D. A. Shah and R. A. Khalil, "Bioactive factors in uteroplacental and systemic circulation link placental ischemia to generalized vascular dysfunction in hypertensive pregnancy and preeclampsia," Biochemical Pharmacology, vol. 95, no. 4, pp. 211-226, 2015.

[10] Y. Abimulyani, N. Nurdiana, and S. C. W. Baktiyani, "Syzygium cumini reduces oxidative stress and matrix metalloproteinase-2 level in endothelial cells induced by plasma from preeclamptic patients," Journal of Experimental and Integrative Medicine, vol. 4, no. 2, pp. 89-92, 2014.

[11] Y. Wang, S. W. Walsh, J. Guo, and J. Zhang, "The imbalance between thromboxane and prostacyclin in preeclampsia is associated with an imbalance between lipid peroxides and vitamin E in maternal blood," American Journal of Obstetrics and Gynecology, vol. 165, no. 6, pp. 1695-1700, 1991.

[12] W. Qu, A. P. Breksa III, Z. Pan, and H. Ma, "Quantitative determination of major polyphenol constituents in pomegranate products," Food Chemistry, vol. 132, no. 3, pp. 1585-1591, 2012.

[13] C. O. De Souza, M. T. S. Peraçoli, I. C. Weel et al., "Hepatoprotective and anti-inflammatory effects of silibinin on experimental preeclampsia induced by l-NAME in rats," Life Sciences, vol. 91, no. 5-6, pp. 159-165, 2012.

[14] H. Takei, Y. Nakai, N. Hattori et al., “The herbal medicines Saireito and Boiogito improve the hypertension of pre-eclamptic rats induced by $N^{\omega}$-Nitro-L-arginine methyl ester," Phytomedicine, vol. 14, no. 9, pp. 591-600, 2007.

[15] V. S. I. Giorgi, M. T. S. Peracoli, J. C. Peracoli, S. S. Witkin, and C. F. Bannwart-Castro, "Silibinin modulates the NF- $\kappa$ B pathway and pro-inflammatory cytokine production by mononuclear cells from preeclamptic women," Journal of Reproductive Immunology, vol. 95, no. 1-2, pp. 67-72, 2012.

[16] H. Takei, Y. Nakai, N. Hattori et al., "The herbal medicine Tokishakuyaku-san improves the hypertension and intrauterine growth retardation in preeclampsia rats induced by $\mathrm{N}_{\omega}$-nitroL-arginine methyl ester," Phytomedicine, vol. 11, no. 1, pp. 43-50, 2004.

[17] A. R. Saxena, S. A. Karumanchi, N. J. Brown, C. M. Royle, T. F. McElrath, and E. W. Seely, "Increased sensitivity to angiotensin II is present postpartum in women with a history of hypertensive pregnancy," Hypertension, vol. 55, no. 5, pp. 1239-1245, 2010.

[18] T. K. Woodruff, R. J. Lyon, S. E. Hansen, G. C. Rice, and J. P. Mather, "Inhibin and activin locally regulate rat ovarian folliculogenesis," Endocrinology, vol. 127, no. 6, pp. 3196-3205, 1990.

[19] F. Herse, R. Dechend, N. K. Harsem et al., "Dysregulation of the circulating and tissue-based renin-angiotensin system in preeclampsia," Hypertension, vol. 49, no. 3, pp. 604-611, 2007.

[20] K.-H. Lim, G. E. Rice, C. J. M. de Groot, and R. N. Taylor, "Plasma type II phospholipase $\mathrm{A}_{2}$ levels are elevated in severe preeclampsia," American Journal of Obstetrics and Gynecology, vol. 172, no. 3, pp. 998-1002, 1995.

[21] T. A. Shouk, M. N. Omar, and S. T. Fayed, "Essential fatty acids profile and lipid peroxides in severe pre-eclampsia," Annals of Clinical Biochemistry, vol. 36, no. 1, pp. 62-65, 1999.

[22] A. C. Staff, T. Ranheim, and B. Halvorsen, "Augmented PLA2 activity in pre-eclamptic decidual tissue - a key player in the pathophysiology of 'acute atherosis' in pre-eclampsia?" Placenta, vol. 24, no. 10, pp. 965-973, 2003.

[23] R. S. Bowen, Y. Zhang, Y. Gu, D. F. Lewis, and Y. Wang, "Increased phospholipase $\mathrm{A}_{2}$ and thromboxane but not prostacyclin production by placental trophoblast cells from normal and preeclamptic pregnancies cultured under hypoxia condition," Placenta, vol. 26, no. 5, pp. 402-409, 2005. 
[24] C.-J. Lee, L.-G. Chen, W.-L. Liang, and C.-C. Wang, "Antiinflammatory effects of Punica granatum Linne invitro and in vivo," Food Chemistry, vol. 118, no. 2, pp. 315-322, 2010.

[25] B. Romier-Crouzet, J. Van De Walle, A. During et al., "Inhibition of inflammatory mediators by polyphenolic plant extracts in human intestinal Caco-2 cells," Food and Chemical Toxicology, vol. 47, no. 6, pp. 1221-1230, 2009. 


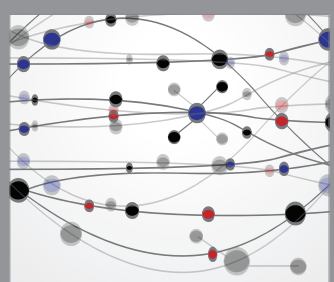

The Scientific World Journal
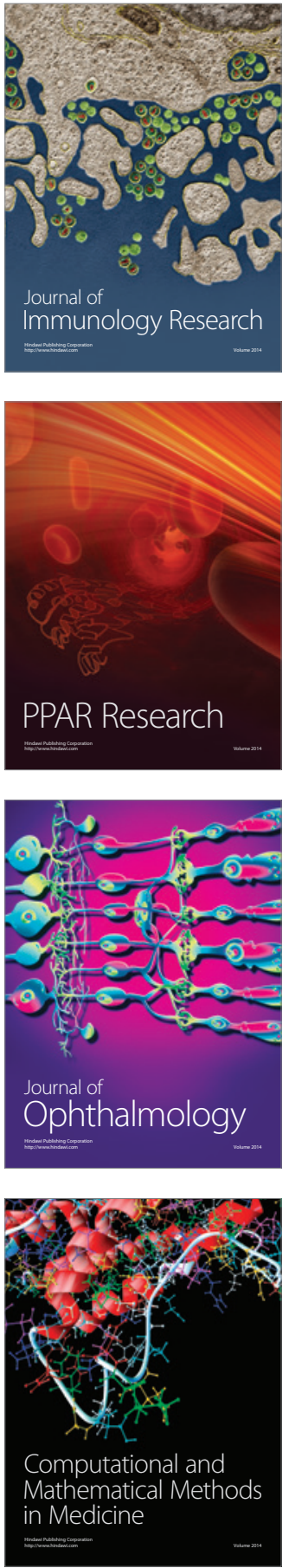

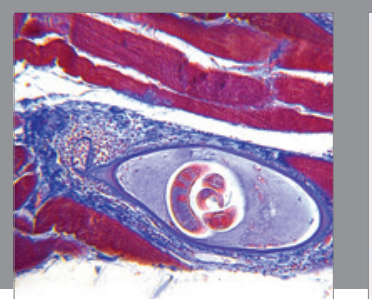

Gastroenterology Research and Practice

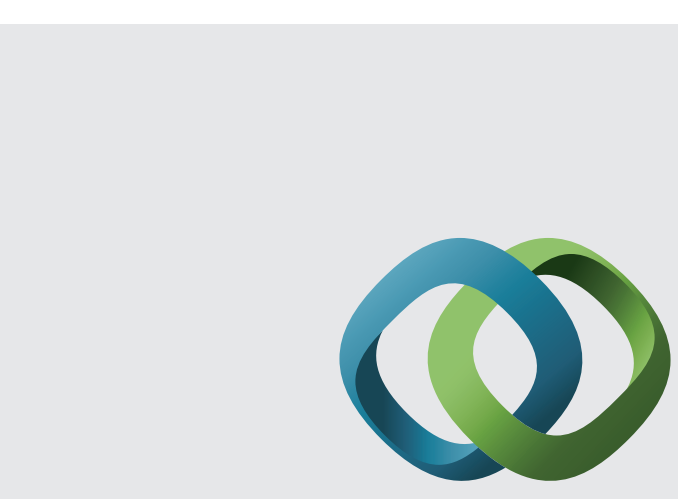

\section{Hindawi}

Submit your manuscripts at

http://www.hindawi.com
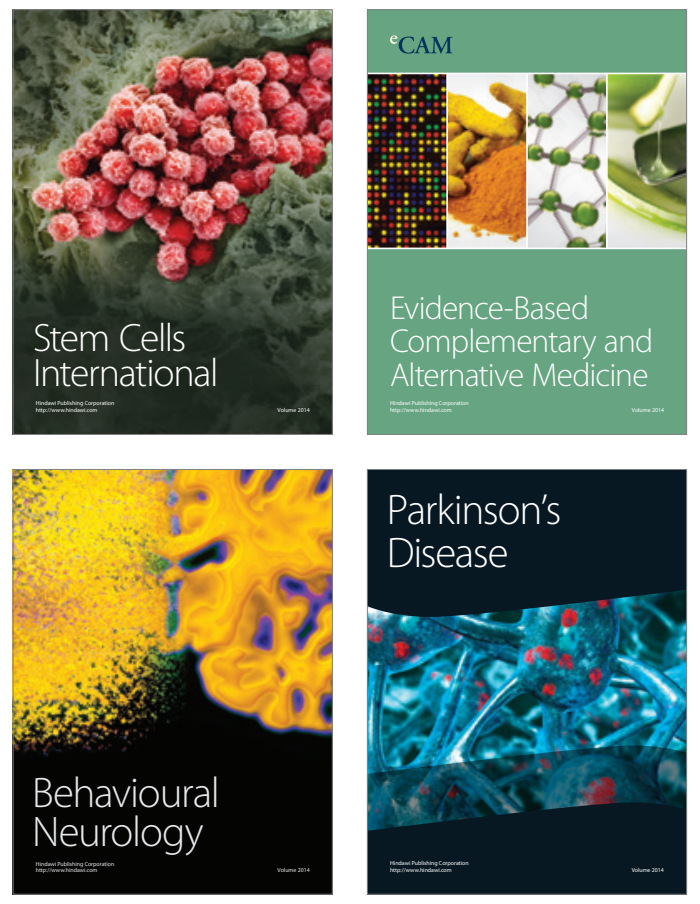
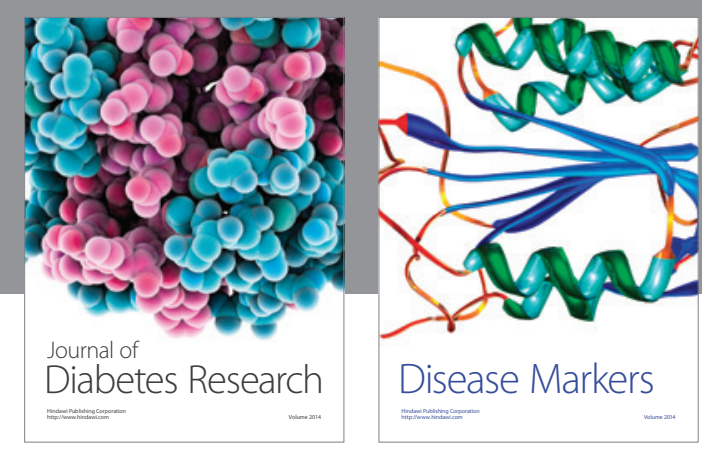

Disease Markers
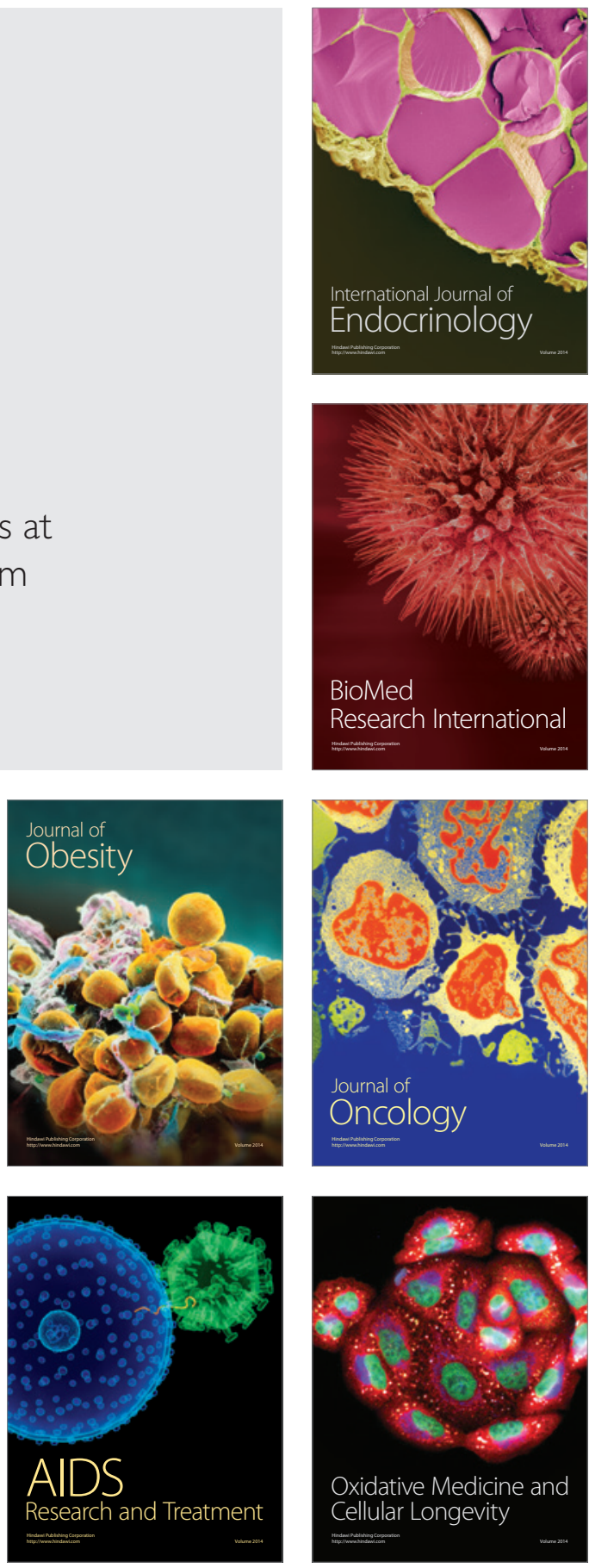